\title{
COMIC STRIPS: A REFLECTION OF THE AMERICAN SPIRIT
}

\section{Ekawati Marhaenny Dukut'}

Abstract: Popular culture by definition includes customs, beliefs and practices, which is massed produced and shared by a society: It can include a best selling magazine, film, food or drink products. It is widely enjoyed by the society because of its cheap price and meets the consumer's needs. Comic strips, is one of those products. Reading comic strips is fun and enjoyable because it does not need full concentration or extra money as a way of passing time, It is massed produced cheaply in popular magazines. newspapers and films. Although it is a way of passing tin e, it is also a way of learning about the American histor; polifics, ecunomy, society and spirit of honesty: freedom and the hope of a better future. The comic strip, to say briefly. is a reflection of the American spirit.

Key words: Comic strips, popular culture, American spirit.

\section{INTRODUCTION}

Culture is a term often used to reflect fine art or the "highbrow" (Wilson, 1995:4) of activities and interests that only highly educated professionals do. The anthropologists, Ember and Ember (1985:485) further explain that culture is a set of the leamed behaviors and beliefs that are characteristic of a particular society or situation. On a similar view the linguist, Lado (1981:111) defines culture as "structured systems of patterned behavior". In other words, it is everything that occurs in a society - all of the customs and practices that are handed down from one generation to another generation.

1. Dra. Ekawati Marhaenny Dukut, M.Hum. is a lecturer at the Faculty of Letters, Soegijapranata Catholic University, Semarang. 
Culture is categorized into elite culture, popular culture and mass culture (Wilson, 1995:5). He explains that the elite culture consists of fine art, literature and classical music and is sometimes referred to as "high culture". Popular culture, on the other hand, is basically the culture of everyone in a society. Mukerji and Schudson (1991:3) refer to it as the "beliefs and practices, and the objects through which they are organized, that are widely shared among a population. Here, Wilson continues by quoting Ray B. Browne which states popular culture as

The cultural world around us - our attitudes, habits and actions: how we act and why we act; what we eat, wear; our buildings, roads and means of travel, our entertainmaent, sports; our politics and religion, medical practices; our beliefs and activities and what shapes and controls them. It is, in other words. to us what water to fish; it is the world we live in.

Historically, in the nineteenth century, the term popular culture has taken over the term folk culture. This means that popular culture belongs to the peasant's, the non-elite's, or the ordinary people's culture. Because nowadays, it refers to the mass production of for example: cheap paperback novels, Levi's jeans and McDonald's hamburgers - popular cultuie is used interchangeably with mass culture that are mass produced and shared through the mass media.

In his lecture, Dr. J. David Slocum of New York University (27 June 2001), American Popular Culture includes the films on the cinema or television, country music, quilt making, sports, gambling, food, fashion, quiz, drinking, the newspaper and magazine articles, talk shows on the radio and television. Thus, if this is related to Brown's and Wilson's opinion above - cartoons which appear as films or comic strips in the newspaper or magazines which are mass produced is also a part of popular culture.

\section{COMIC STRIPS}

Comic strip characters are usually drawn on students' pencils, erasers, lunch boxes, advertisements and shown on television or newspapers so people can see their comical aspects. Its themes are mostly about children and pet frolics (http://www.geocities.com/ SoHo/5537/hist.htm) that adults take it for granted and consequently from an academic view point, Veron (1976:298) stipulates that not many scholars are interested in making use of it as their research project. In my opinion, this is odd. Fortunately, Berger (1976:298) 
$\Delta$

Perpustakaan Unika

and Canaday (1970:234) supports this opinion by pointing out that popular culture is bulldozing its way through the grooves of the academe because graduate students of American Studies are seriously studying this important dimension of culture.

In addition to the feeling of enjoyment, reading comic strips in a political sense can deliver critical points about a society's heated problem. Dialogues, which exist in the comic strips, can show the relationship of those being criticized and the one doing the criticizing. There is a suggestion that the criticizer hopes to find the answer to the heated problem faced. In other words, comic strips are not just an artistic creation that shows off its humorous aspects but it also contains a plea, a suggestion or an advice of the ethical standards of a society.

When digested in depth, American Studies scholars believe that reading a comic strip is one way of learning the American culture. It can show the creator's world, which reflects the cultural happenings of the society, the economy and the political situation. This is in line with Smith (1960:7) who believes that a study of a particular work of art is "at once biographical, historical, sociological, and literary".

Who are the most popular authors and what forms of comic strip are popular? What is its relationship to the cartoons? How did comic strips enter into the American culture? How has it developed itself? How does it reflect the American spirit? Answers to these questions are among those that will be discussed in the following paragraphs.

\section{TYPES OF CARTOONS}

According to the Microsoft (a) Encarta (\$) 98 Encyclopedia (1997) and The Encyclopedia Americana: International Edition (1978), the cartoon is a drawing made on paper in preparation for and in the same size as a painting, tapestry, mosaic, or piece of stained glass. Since the 1840s the term has come to also mean any humorous, satirical, or opinionated drawing, typically one printed in a newspaper or magazine, with or without a short text. Rather than the drawing, the text - cast within the cartoon as speech or set as caption - may be the bearer of the joke or the witticism. The earliest cartoon, which has been preserved were by the Italian painter, Michael, who in 1516 drew the wall tapestry of the Sistine Chapel of Rome. The other well-known artist was the Italian, Leonardo da Vinci with his The Virgin and Child with Saint John the Artist and Saint Anne in 1499. 
Depending on their purpose, most cartoons fall into one of several different categories: editorial, gag, illustrative, animated cartoons and comic strips.

\section{Editorial/ Political Cartoons}

The editorial cartoons are also referred to political cartoons, which serve as a visual commentary on current events. They may communicate the political viewpoint of the cartoonist or add depth to an editorial opinion article in a newspaper or magazine. Often a cartoonist would deliberately distort or make an exaggeration of a person's feature in a caricature, to make fun off well-known figures to sway the public opinion. For politicians, humorous stories and witty repartee have often been as effective means of public communication as serious discussion and debate (Clark, 1977:424). Henceforth, it is understood that there is no better way to criticize the political system than to put them in cartoons.

America's well-known cartoonists of the editorial/ political section are among others: Thomas Nast, Boardman Robinson, Bill Mauldin, Jeff Macnelly, and Mike Luckovich. An example of the American caricature cartoonist's work can be seen in figure I below, where David Levine exaggerates Rudyard Kipling (The Encyclopedia American: International ed., 1978:660) and Albert Hirschfeld's satire of Franklin D. Roosevelt (The Encyclopedia American: International ed., 1978:661).

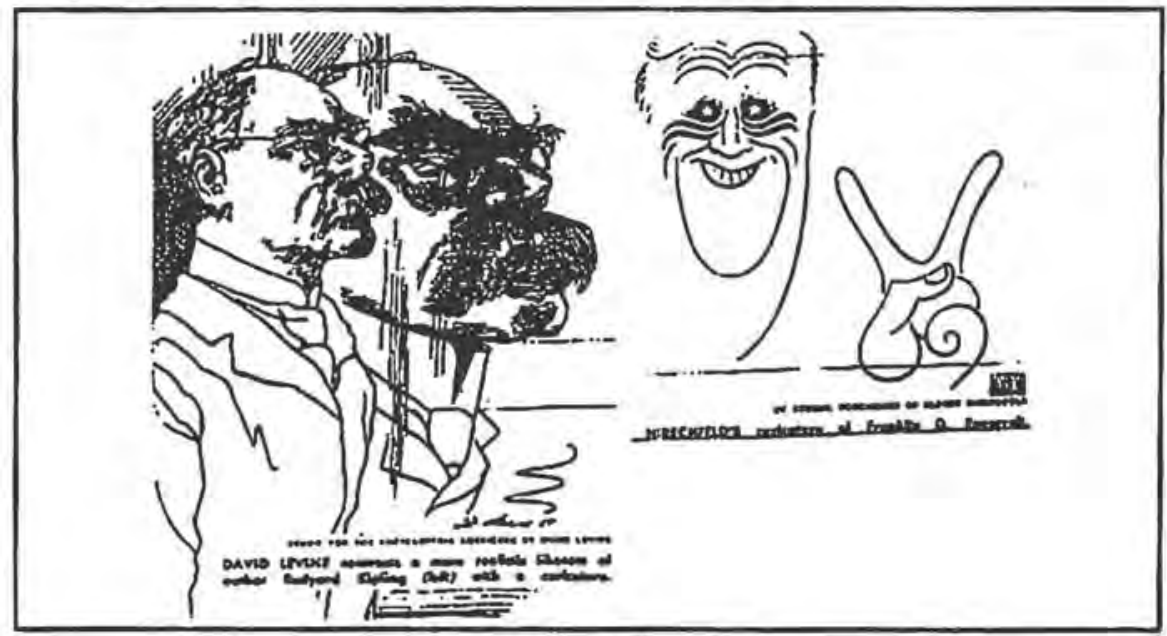

Figure I 
E.M. Dukut, Comic Strips: a Reflection of the American Spirit

\section{Gag Cartoons}

Gag cartoons, consist of a single panel and are often accompanied by a caption, usually placed outside the panel. The characters would appear only once, rather than recurring as in other types of cartoons. It usually makes fun of groups of people rather than lampooning individuals. They are often found in The New Yorker magazine and on greeting cards. The well-known gag cartoonists are James Thurber, Charles Adams and Peter Amo.

\section{Illustrative Cartoons}

Illustrative cartoons are used in conjunction with advertising or leaming materials. They illuminate important points, highlight special aspects of a new product, or give visual representations of processes to reinforce an advertisement or educational text. For example, Charles Schulz's Peanuts began to appear in life insurance advertisements in 1985. In a similar way, Toucan Sam became a trademark for Froot Loops cereal.

\section{Animated Cartoons}

The animated cartoons are really those funny and comical cartoon creatures that we see on television everyday. Most of the time the characters are animals, which can speak and are lovable, and surprisingly intellectual that they have human qualities in them. Because of these features, children enjoy watching them and it is a good way for the cartoonist to indirectly give some moral teaching to them. One of the most enjoyed pop cartoons of 1997 was Walt Disney's Lion King.

\section{Comic Strips}

Finally, the comic strips are actually narratives told by means of a series of drawings arranged in horizontal lines, or strips or rectangles called panels and read like a text from left to right. The term applies specifically to comics found in newspapers. Characteristically, it usually depicts the adventures of one or more characters in a limited time sequence.

The dialogue is represented by words encircled by a line, called a balloon, which issues from the mouth or head of the character speaking. Sometimes captions also appear. Black and white comics usually appear in daily newspapers, and its feature occupies a single strip. The colored ones usually appear in Sunday editions in a special section and may occupy part or all of a page. 
An example of the Washington Post's Sunday edition of comic strips can be seen in the appendix of this article. Whereas, the history of America's first comic strips, its development, impact on society and other media is discussed in the following paragraphs.

\section{ORIGIN AND DEVELOPMENT OF COMIC STRIPS}

Some characteristics of the comic strip, including the balloon are derived from the cartoons of English caricaturist of the $18^{\text {th }}$ and $19^{\text {th }}$ centuries such as William Hogarth, Thomas Rowlandson, James Gillray, and George Cruikshank.

From the beginning of 18890 s the comic strips appeals both to young and adult readers. The Encyclopedia American: International ed. describes that comic strips passes through four distinct periods:

\section{First Phase}

The initial phase marks the emergence of the first great newspaper comic strip artist such as Richard Felton Outcalt and James Guilford Swinnerton. These artists began to apply their cartooning abilities to fulfill the needs of a press that sought mass readership. The man named Outcalt to the history of American comics is the first American who draws the essential characteristics of a comic strip. His first series, the Hogan's Alley was first published on 5 May 1895, in the New York Sunday World.

The setting of the cartoon is usually a squalid city tenement that has backyards filled with dogs and cats, tough characters and ragamuffins. One of the urchins is a flap-eared bald-headed, oriental-looking child with a quizzical, yet knowing smile. He is often dressed in a long, dirty nightshirt, which Outcalt used as a placard to comment on the cartoon itself. The printers experimenting with yellow ink chose the urchin's nightshirt as a test area. The yellow is reported a success and so is the Yellow Kid as it became known. Because of this color, people refer to newspapers also as "yellow journalism" (Wilson, 1995:104).

The Yellow Kid series turns to be such a success that it helped sold many papers in 1898 that it rapidly became a newspaper staple (McLuhan, 1972:89). Two other early comic strip cartoons, each having its own supporters who considered their favorite the first true comic strip, were the Katzenjammer Kids by Rudolph Dirks, which first appeared in The American Humorist in 1897, and Little Bears by James Guilford Swinnerton, which 
first appeared in the San Farancisco Examiner in 1892. Pictures of the mentioned cartoons, can be seen below:

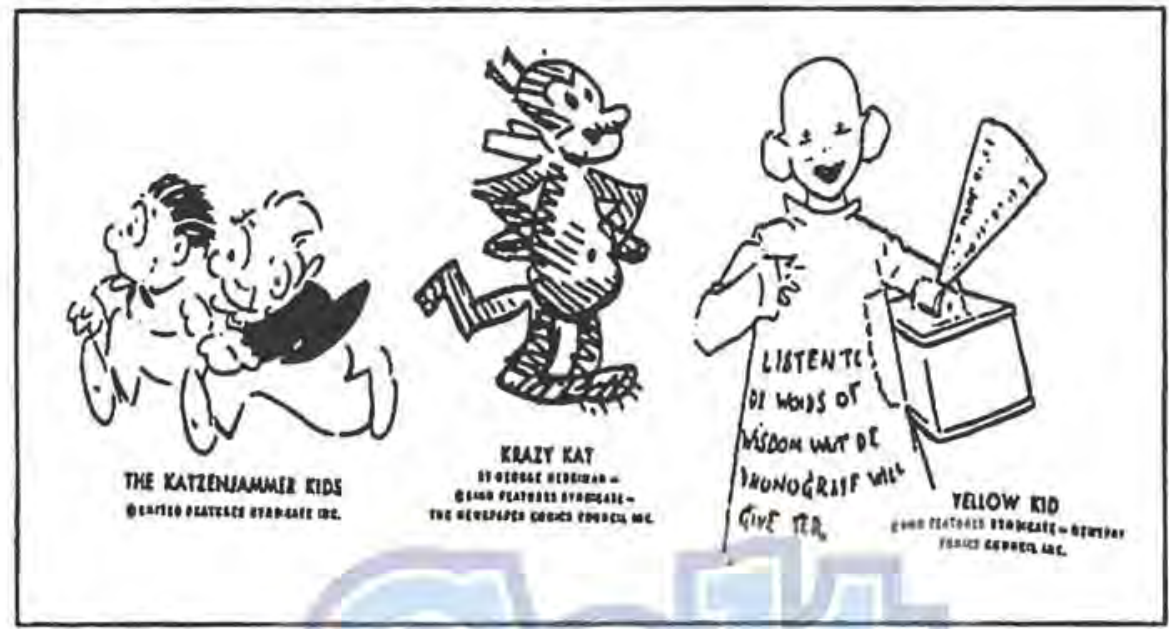

Figure 2

The Golden Age

Newly formed newspaper syndicates, such as King Feature in 1914, has made mass circulation of comics possible. Every small town newspaper can obtain, for reprinting, matrices of the strips from the syndicates, which employs the comic strip artists.

Eventually, American comic strips are distributed worldwide and established its golden age. Cartoonist such as George Herriman with his Family Upstairs appeared in 1910 with his distinct Krazy Kat character. More than any other strips, Krazy Kat appeals to intellectuals and the literary minority who at first rejects comics as worthy of their intention. Even the president, Woodrow Wilson, always finds time to read it before his cabinet meetings. John Alden, in 1926, has also composed a ballet about it and the distinguished poet E.E. Cummings has written an appreciative introduction to the collection of the strips' hardcover edition volume. In addition, Chic Young's Blondie is also regarded as the most widely syndicated comic strip of the mid twentieth century. 


\section{The Third Phase}

Until the 1930s the comic strips were essentially humorous exaggerations of American life and manners. Until the end of World War II, the trend moves towards adventure strips. There emerged such heroes like Roy Crane's Captain Easy and Buz Sawyer. It was also the decade for science fiction adventures, such as Superman, Flash Gordon, Buck Rogers, Brick Bradford and Al Capp's Li'l Abner comic strips that dwell on domestic problems emerged.

\section{Postwar Comics}

After World War II, there is a fairly sharp return to humorous comic strips. This is stimulated by the creations of two of the most enjoyable comic strips in the history of the medium, i.e. Walt Kelly's Pogo (1949) and Charles Schulz's Peanuts (1950). Thirty-two out of thirty-nine new comic strips produced in 1956 to 1960 are purely humorous. Among the popular cartoons to mention are Dick Tracy, Wizard of Id, and Beetle Baily. This phase is often regarded as the "funnies".

\section{IMPACT ON SOCIETY, MEDIA AND OTHERS}

From the discussion above, it is evident that even though at one stage comic strip is overlooked by scholars, it has however, been proven to make an impact on the society and media. Reflecting on the former president, Woodrow Wilson, who makes time to read Krazy Kat, it shows a psychological factor of him looking at his day from the easy and humorous perspective rather than a hard, stressful day.

Series of comic strips do not only reflects the American life but also molds it. Comic strips manage to inspire plays, books, toys, popular songs, musicals, ballets, motion pictures, radio and television series. The following is a discussion on some of the effects.

\section{Music}

In music, there are a number of songs that are derived from these comics i.e. Yes, We Have No Bananas and Barney Google with the Goo Goo Googly Eyes in 1920. Ten years later, there are musical attributes to Popeye - the Sailor Man, Little Lulu, L'l Abner in 1959 as well as a Broadway Musical It's a Bird...It's a Plane...It's Superman whose intention is to satirize the comic strip Superman in 1966. 
E.M. Dukut, Comic Strips: a Reflection of the American Spirit

\section{Film, radio, Television}

In films, radio and television, comic strip characters are found everywhere and at anytime. From 1931, live actors are used in feature films for Blondie, Captain Midnight, Jungle Jim, Superman, Tarzan and many others. The radio station makes afternoon serials on Dick Tracy, Little Orphan Annie and Buck Rogers. The television uses both live actors and cartoon figures in the ever popular The Flinstones, Dennis the Menace, and Batman.

\section{Food and Fashion}

The influence of the comic strips characters has also affected the American culture's eating habits. For example, the citizens of the spinachgrowing community in Texas have erected a statue of Popeye in honor of the comic character that made America spinach-conscious. It, too, has affected American fashion. At the tum of the century, whole generations of American boys are dressed like Popeye, Superman, Barman and the like. The teenage girls are inspired to wear a collection of hats from Penny and Brenda Starr. Other merchandise includes Al Caps' Shmoos such as in their glassware, underwear, soap, fishhooks, birthday cards, and household deodorizer products.

\section{Education}

Because comic strips have such an influential market in books, some fear that it will disrupt children's education. However, educators eventually see the beneficial side of it. With the nine out of ten children who have their first exposure to print by reading the comics and whose habit is continued to their high school years, felt overwhelmed with the idea that some classical subjects can be formatted into comics. Also educational researchers find that the 10,000 vocabulary words offered by the comics has helped stimulate the increase of children's reading habit.

\section{Language}

In addition to the four categories above, the comic strip has influenced modem language that has been permeated with idioms and onomatopoeic words created. For example, the code word for the Allied Forces on D.Day is "Mickey Mouse" and Thomas A. Dorgan's strips have introduced the slang words such as "twenty-three skidoo, cat's pajamas, yes-we have no bananas" to Americans. 
In summary, just like the political cartoons which affected the political life of the Americans - the impact of comic strips on the society and other medias have molded them. Comic strips contribute to the development of the national ethos. Their creators, seeking the widest possible audience has reflected that audience and their thinking. To see how this is done and how it reflects the American spirit, a brief argument on Charles Schulz's Peanuts is discussed below.

\section{CHARLES SCHULZ'S PEANUTS}

One of the most successful and widely loved comic strip by all ages is Charley Schulz's Peanuts wityh its characters: Charlie Brown, his sister Sally, his smart dog Snoopy, his friends Lucy, Linus, Schroeder, Peppermint Patty, Marcie and the bird Woodstock. Quoting Pierre Couperie and Maurice C. Hom, Berger (1976:298) notes that,

his hernes are not animals but preschool-age children, "led" by Charlie Brown. whose faith in human nature (and in that of his little comrades) is always cruelly deceived. His chief tormentor is a scowling, cynical little girl, a real child shrew, named Lucy van Pelt. Linus, Lucy's brother, is a precocious, delicate intellectual whose nerves give way with the loss of the blanket he always carries around him to reassure himself. Schroeder, whose greatest pleasure is to play Beethoven on his toy piano, the dirty Pig-Pen, and several others complete this childish team, to which must be added Snoopy the hedonistic young puppy who is very pleased with living.

Schulz, or to be more complete, Charles Monroe Schulz, was born in 1922 in Minneapolis, Minnesota. Very early when he was two days old, he was nicknamed "Sparky" by his family. In this case, his family was influenced by Barney Google's horse character named Sparkplug (Microsoft @ Encarta (898 Encyclopedia, 1997). Up to now he is known, as "Sparky" to his friends and because of that it may be the start of Schulz thinking of being a cartoonist as his profession.

When graduating from high school, Schulz became interested in an advertisement of an art school course found in a match-book cover. Feeling as the only fairly person, he took up work as a cartoonist. Schulz says that in being a cartoonist,

you have to be fairly intelligent- if you were really intelligent you'd be something else; you have to draw fairly well- if you drew really well you'd be a painter; you have to write fairly well- if you wrote really well you'd be writing books... (Conrad, 1970:243). 
Another factor is perhaps Schulz's simplicity. He uses the same old characters with the same kind of characteristics. Consequently, it becomes easy to grasp the comic strips, which only comes up briefly each day in the newspaper. So, when, for example, in one of the cartoons Linus has no lines to say, many readers could more or less substituted a line for Schulz, which in reality is not far away from Schulz's own line.

Consider the comic strips of Peanuts (see figure 3 ), which is published in the Washington Post last 6 August 1995. Knowing how much Linus loves his blanket; readers can still see the comical side of it when being told that after Snoopy help get his blanket down from a tree - snoopy decides to get rid of it again. This is because Linus did not even bother to thank Snoopy for all the hard struggle of climbing up a tree to get his lovable blanket. It is hard because everyone knows that in reality a dog cannot climb a tree - but in this case, Snoopy did. At the same time, reader's are asked to make a retrospect of why one often do not give respect to another's hard work.

Schulz's themes are always simple and about simple things. For example, in a child's mind the idea of a kid starting up his day and about what to do when he cannot dance - is possibly like how Schulz drew in the cartoons (see figure 4 ).
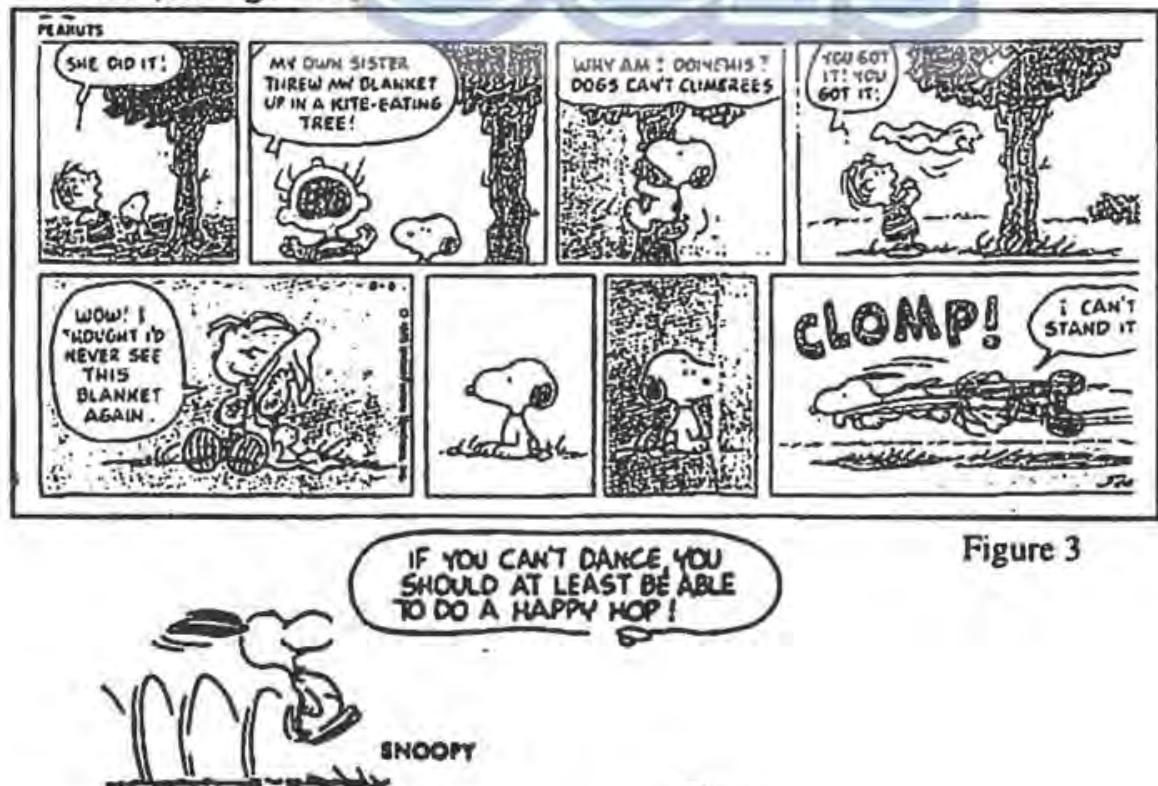

Figure 3 
Schulz's use of terms like the "happy hop" has a folkish ring to it. It is a kind of term that ordinary people would say - not those belonging to intellectuals, so immediately his cartoons are popular and massively produced. The Peanuts cartoons are bought and read just by every old and young people because the themes are familiar and often touches very ordinary things and homely events. Yet, it may be for this ordinariness that scholars had once taken his cartoons for granted. Nowadays, people see it as a popular culture that needs to be researched on.

In addition to free entertainment, Schulz manages to transfer a political and social satire. In the comic strips published by the Washington Post of 16 July 1995 (see figure 5 below), Schulz is actually criticizing the Vietnam War. His purpose is possibly asking a plea to those people in the high ranks to give more attention to their "little" soldiers. When reflected to the idea of the American Spirit, readers can see that everyone is eligible to pursue their own American dream by giving attention to Snoopy's criticism to Spike about duty for the infantry.

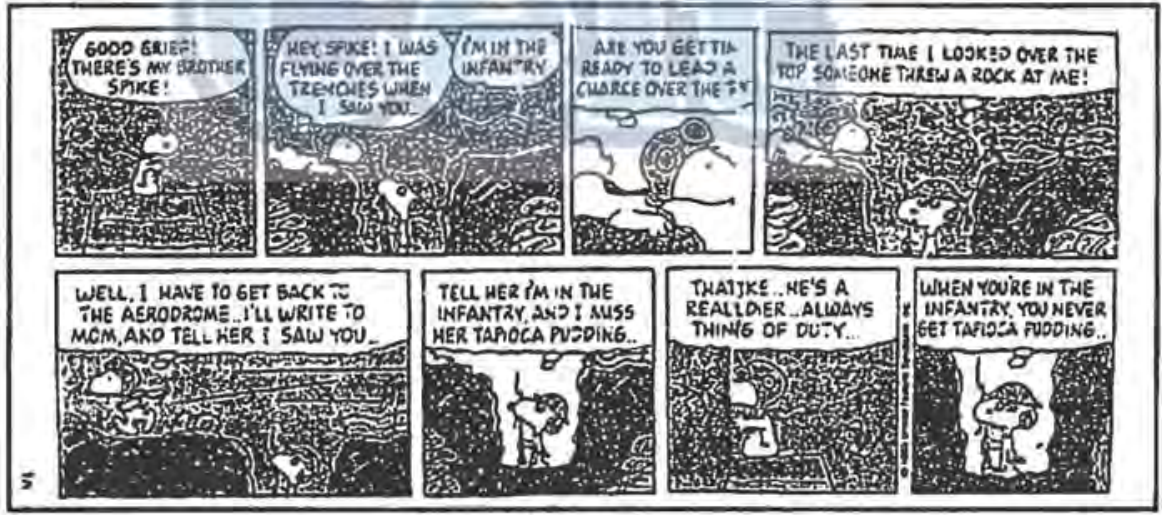

Figure 5

Snoopy has done a number of things for the American people. He brings the American Spirit alive, i.e. he brings the hope for a better future by bringing forth the danger of a society full of egoists who pursue on their individual wants to reflect themselves so justice can prevail. The cruel harsh world that is often kept under cover can now be freely expressed through Schulz's comics. Snoopy, who enjoys living, has ultimately shown that people are free to do as they please, no matter what status or rank of society they live in. Once people have the courage to do something, therefore the wish 
can be turned to reality. Comic strips offer a moral guidance to keep people on the right track. More importantly, comic strips enable a release on the aggressions felt by reading and seeing the remarkably cute, funny and laughable characters that exemplify the fools living around a society (see appendix for more comic strips).

So, it is not surprising that Peanuts deserve the acclaim for being an American Popular Culture product. It is a best seller and with this example, scholars should try to find what other American Spirit is in store in other popular comic strips!

\section{REFERENCES}

Anderson, Benedict. "Cartoons and Monuments: the Evolution of Political

Communication Under the New Order". In Political Power \& Communication. London: Califomia Press, 1978.

Berger, Arthur Asa. "Peanuts: the Americanization of Augustine". In Humor in America:

An Anthology edited by Enid Veron. New York: Harcourt Brace Jovanich, Inc., 1976.

Canaday, John. "Pop Art Sells On and On - Why?" In Pop Culture in America edited by David Manning White. Chicago: Quadrangle Books, 1970.

Clark, Thomas D. "The Pageantry of American Political Humor". In The Comic Imagination in American Literature edited by Louis d. Rubin, Jr. USA: Voice of America, 1974.

Conrad, Barnaby. "You're a Good Man, Charlie Schulz". In Pop Culture in America edited by David Manning White. Chicago: Quadrangle Books, 1970.

Ember, Carol R. and Melvin Ember. Anthropology, $4^{\text {th }}$ ed. USA: PrenticeHall Inc., 1985.

hutp://www.geocities.com/SoHo/5531/hist.htm, 18 August 2001.

Lado, Robert. Linguistics Across Cultures, Ann Arbor:The University of Michigan Press, 1978.

Microsift @ Encarta @ 98 Encyclopedia. A Microsoft computer software. Nashville: Microsoft Corporation, 1997. 
76 Celt, Volume 1, Number I, December $2001: 63-77$

McLuhan Marshall. "The Comics". In The Pop Culture Tradition: Readings with Analysis for Writing edited by Edward M. White. USA: W.W. Norton \& Company, Inc., 1972.

Mukerji, Chandra and Michael Schudson. Rethinking Popular Culture:Contemporary Perspectives in Cultural Studies. Oxford: University of Califormia Press, 1991.

Slocum, J. David. "American Popular Culture". A lecture delivered to American Studies Summer Institutes program at New York University, New York, USA, 27 June 2001.

Smith, Henry Nash. "Can American Studies Develop a Method?". In Studies in American Culture: Dominant Ideas \& Images edited by Joseph J,. Kwiat and Mary C. Turpie. Minneapolis: University of Minnesota Press, 1960.

The Encyclopedia Americana: Interiational edition, vol. 5, 7. USA: Americana Corporation, 1978.

Veron, Enid (ed). Humor in Anterica: An Anthology. New York: Harcourt Brace Jovanich, Inc., 1976.

White, David Manning (ed). Pop Culture in America. Chicago: Quadrangle Books, 1970.

Wilson, Stan Le Roy. Mass Medial Mass Culture: An Introduction, $3^{\text {td }}$ ed. New York: McGraw-Hill, Inc., 1995. 
E.M. Dukut, Comic Strips: a Reflection of the American Spirit ?

\section{APPENDIX}

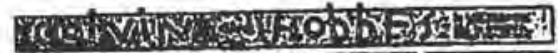
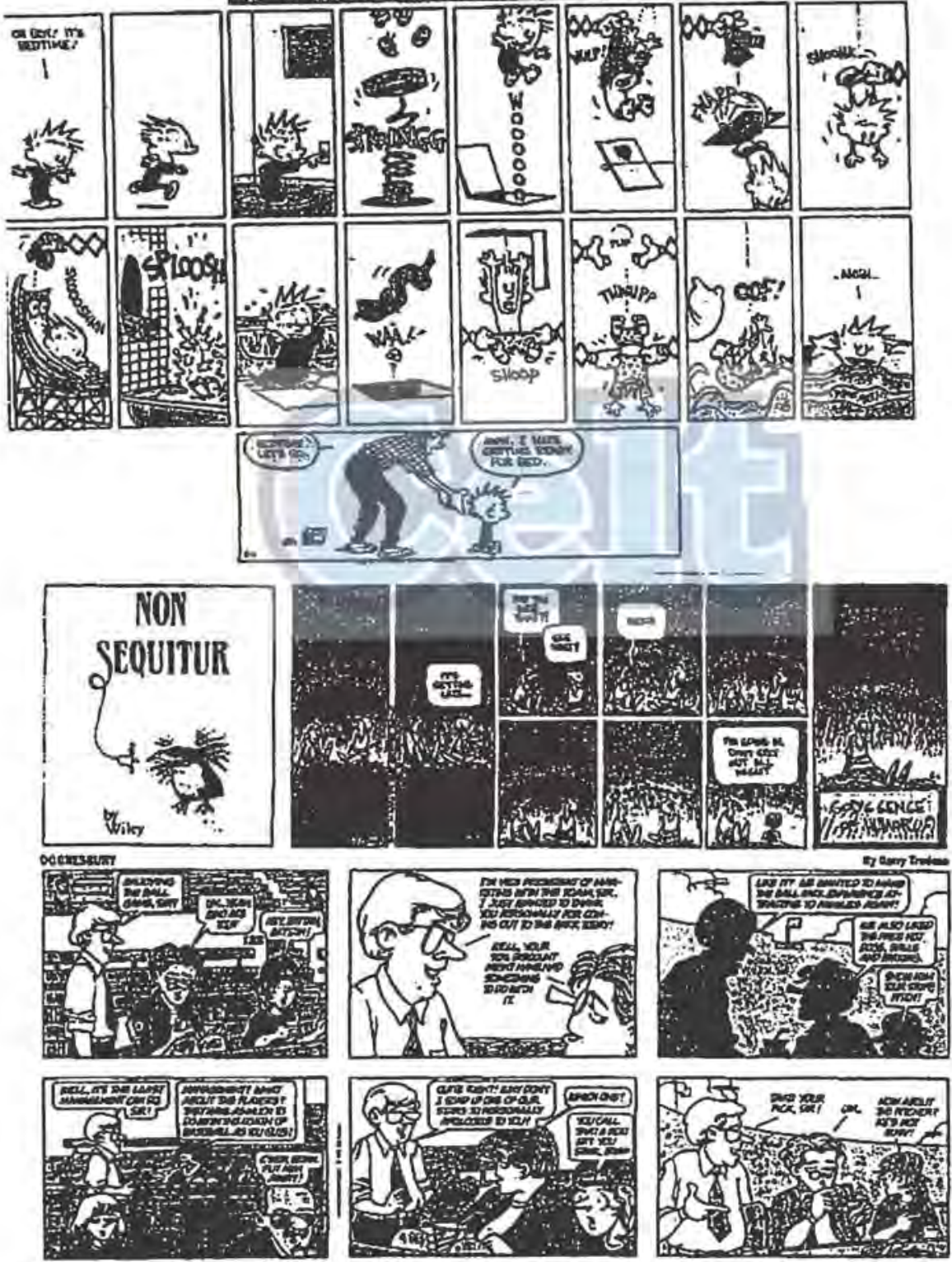